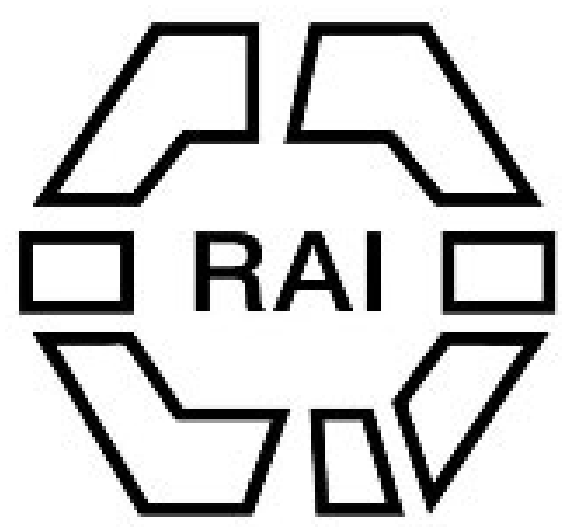

The Atharaka

Author(s): Arthur M. Champion

Source: The Journal of the Royal Anthropological Institute of Great Britain and Ireland, Vol. 42 (Jan. - Jun., 1912), pp. 68-90

Published by: Royal Anthropological Institute of Great Britain and Ireland

Stable URL: http://www.jstor.org/stable/2843233

Accessed: 28/06/2014 11:58

Your use of the JSTOR archive indicates your acceptance of the Terms \& Conditions of Use, available at http://www.jstor.org/page/info/about/policies/terms.jsp

JSTOR is a not-for-profit service that helps scholars, researchers, and students discover, use, and build upon a wide range of content in a trusted digital archive. We use information technology and tools to increase productivity and facilitate new forms of scholarship. For more information about JSTOR, please contact support@jstor.org. 


\section{THE ATHARAKA.}

[With Plate X.]

By Arthur M. Champion, A.D.C.

\section{INTRODUCTION.}

BEING entirely ignorant of the science of anthropology I feel quite incompetent to write anything in the nature of a study of this people, but, having spent altogether a month or more amongst them, I have determined to record my observations of a people at present so little known, in the hope that they may be of some little use to others. During the taking of the census I had unique opportunities for studying the domestic habits, and I think I may say everything that I record under this heading I have seen with my own eyes. I have tried to get all information corroborated, and have discarded a heap of stuff that has not been confirmed by at least two separate authorities.

A fair amount of information was obtained from Government Chiefs, but by far the major portion from elders with whom I happened to get into conversation.

\section{ETHNOGRAPHICAL.}

In external appearance the Atharaka neither resemble the Akamba nor the Akikuyu, though perhaps they are closer in this respect to the Akikuyu. The colour of the skin varies more than among the Akamba, I have seen Atharaka jet black, but on the other hand I have seen others quite coffee colour. A very noticeable feature is the marked degree in which the feet are turned inwards. The feet are, I should say, much larger than among the Akamba. Another prominent feature is the length of the arm; the position assumed by a woman when she has nothing in her hand is very suggestive of the ape. The body is bent forward from the hips, and the long arms hang down in front almost to the knee. In fact, the whole attitude gives the impression that a hurried retreat would be on all fours. The young men remind one not a little of the ancient Egyptian types. The shoulders are broad, and the whole body tapers down towards the feet. They are athletic looking compared with the Akamba Anake. The girls are usually well-built, sturdy, and healthy looking.

The language has more the intonation of Kikuyu than Kikamba, the $L$ being usually replaced by the $R$ as in Kikuyu, though I am informed that a Mumoni Mkamba can more readily make himself understood to an Atharaka than a Mkikuyu. ${ }^{1}$

1 Mumoni is the name given to that part of Ukamba which borders on the Tharaka country, and the Akamba of that part cannot pronounce the $\mathrm{L}$ as it is pronounced by the Machakos and Kitui Akamba. 
The race as a whole are very hot tempered and excitable, and an argument rapidly flares up into a brawl, and from a brawl into a fight. Even the old men and chiefs get very excited over the most trivial matters, and rage in the Baraza like angry children. It is with the greatest difficulty that any order can be kept, as they all want to talk at once. On these occasions they seem unable to remain seated, and it is only with the greatest patience that order can be restored.

As a race the Atharaka are exceedingly proud, and though some of them are beginning to show a willingness for work, they are very independent, and unless everything is arranged for their convenience and they are treated better than their fellow-workers, who are frequently Akikuyu, they will go off in a huff. Several cases have recently been brought by Atharaka claiming wages after they have broken their contract by running away before they had completed a month's work. Such people doubtless return to their country in a bad frame of mind and spin long yarns to their friends. As soon as they come to realize the conditions under which native labour is carried on they will, I think, prove themselves useful people, as they not only strike me as being harder workers that the Akamba, but also very skilful carpenters, etc. Their brain power, however, would seem to be of a very low order, and two Atharaka whom I have had as personal servants for nearly a year show little or no aptitude for picking up any Kiswahili.

They are avaricious to a degree, and will accept presents freely and ask for more, but will give nothing in return; exorbitant bribes will not induce them to bring milk or eggs. Their ideas of trade are very one-sided, and the prices they demand for goats, wax, hides, etc., are ludicrous ; the trouble at present is that they are not in want of rupees, so that they can afford to stand by their price or return with their produce. The attempt made to introduce trade, using the rupee as a medium, was in consequence a complete failure ; a most lively trade could, however, be carried on in beads and wires with great advantage to the traders. At present the Akamba are exchanging their cast-off beads and ornaments for the Tharaka produce, which the wily Akamba in turn sell to the traders.

It had generally been supposed that the Atharaka were a poor people, but after spending many days walking about among them I am convinced that this is not the case. Though the herds of cattle are not so large as those of the Akamba, nevertheless every man of any standing possesses from ten to a dozen head. Goats, honey barrels, and tobacco are possessed by everybody.

As a whole the race seem very free from disease, but I was struck by the number of old people who were blind. On Keua Hill I came across a settlement of natives who seemed to be suffering from syphilis, the children being covered with the most offensive sores. The whole community seem to be prostrated by the disease. I was informed that it was not syphilis, and that such visitations had occurred before, and that after working its way through the natives of the settlement it would die out and most of the sufferers would recover.

As to the origin of these people it is very difficult to say, but they all seem convinced that their forefathers came from the south-east, and that they occupied 
the Kitui District before the Akamba crossed the Athi, but that they were gradually driven back by the Akamba till they sought refuge amongst the hills which they now occupy. Some say that the Galla were in the country when the Atharaka were driven back, whilst others say that they found the country uninhabited. The Atharaka had wars with the Akamba and the Akituu, and I am informed by Mzee Kamundi that his uncle who was a chief before him was not very long ago driven back from Cha Ngondo by the Akamba, and the Atharaka have never ventured to return. According to the same authority the Masai visited them a long time ago, but were driven out by the Atharaka, who used bows as well as spears, and great numbers of Masai were killed. It would be very interesting to compare the customs of these people with those of the Pokomo and other tribes inhabiting the lower reaches of the Tana River. Many customs are similar to those of the Akamba, but there are also many which are entirely different-method of building may be quoted as one of the most apparent. No doubt many Kikamba customs have been absorbed, but I am strongly of the opinion that the Atharaka are not an offshoot of the Akamba, but an entirely different race. From inquiries and observations in Tharaka I should say that the Atharaka have certainly occupied their present country for three generations, as none of the oldest men seem to have any recollection of having lived elsewhere, or of having heard definitely where their fathers lived.

\section{The Coun'try.}

The Atharaka inhabit the Valley of the Tana or Kilaluma River from the Mkong'go River northwards till the Tana River passes under the Ngoro Rock. As far as I know there are no Atharaka living further down the Tana than this point. The Atharaka of the Kitui District live between the Tana and a line drawn from Cha Ngondo through Siri Etumo to the Ngoro Rock. They comprise some five to six thousand souls.

A more or less continuous range of hills runs from Mumoni Hill northwards to Kamabuongo and Mutialu and continues to appear on the left bank of the Tana as far North as Kikingo. A few miles north of Mutialu the Tana has managed to push its way through the range of hills and has cut for itself a deep gorge. Thence the river runs northwards again to make that great bend which is such a peculiar feature on the map of East Africa. It is among these hills and their western slopes that the Atharaka live, there being no habitations on the actual banks of the Tana, though the people are dependent on the river for water during the dry season. The hills are not high, Kamabuongo being about 2,900, and Keua about 3,200 feet above sea level. The Tana at the Ngoro Rock stands at about 1,500 feet. The majority of the rivers only run for a few hours after heavy rains, and the water obtained by digging in the river bed is generally brackish.

This range of hills is a denuded anticline of archean, gneisses, and schists, which afford wild and rugged scenery, but hard marching. Garnets are very plentiful among the gneisses.

After heavy rains, a layer of fine, black, sparkling sand (magnetite) is found 
spread over the top of the quartz sand in the river beds. In some rivers this sand is very plentiful, and is used by the Atharaka for making their weapons and tools. In consequence of the abundance of oxide of iron (hæmatite or decomposed magnetite) the soil is very red in comparison with that of other parts of the Kitui district.

The whole country is covered with bush, exsept where the Atharaka have made clearings for cultivation. Along the banks of the Tana from the village of Mundu wa Ngula to the Ngoro Rock the bush is especially dense and is inhabited by waterbuck, the only species of game left in Tharaka. There are hippopotami in the Tana and a great variety of fish, the best for eating being the moderate-sized white fish with red gills and fins. The multiplicity of native paths render it possible to move about the country with the greatest ease in spite of the bush.

\section{Meteorological.}

The temperature rises very high at midday, I did not have a thermometer with me, but I should say that it would touch at least 105 degrees $F$. in the shade during the hot season. At midday the sun is very oppressive, owing to the stagnation in the atmosphere which sets in about this time of the day. In the early morning and late evening a considerable breeze gets up; in the evening from the Mumoni Hills, and this, though by no means a cool breeze, is a great relief after the heat of the day; in the morning gentle puffs of air seem to come from the Tana River. The cause of this is, I think, the comparatively cool air from the hills and higher ground rushing down the long slope from Mumoni to take the place of the hot air rising out of the Tana valley in the evening.

The rains fall twice yearly, in April-May and again in November-December. In 1910 the rains broke in Tharaka on October 27th, and the spring rains had already broken when I arrived on April 13th, 1911.

\section{Domestic Life and Habits.}

A human being passes through the following grades :-

Males.

1. Karna (up to five years).

2. Kaegi (up to circumcision).

3. Ntheka or Ngoromo (warrior up to marriage).

4. Ntheka Nguru (up to circumcision of first-born).

5. Kisungi (having circumcized child).

In this stage, a man becomes a Mundu Mukuru and is graded by the year in which he was circumcized, viz., Mbabu and Mkilamana.

\section{Females.}

1. Karna (up to five years).

2. Kali (up to circumcision).

3. Idika (up to marriage).

4. Mwiki (married but not yet given birth to a child).

5. Mukaa or Mubiki (up to circumcision of first-born).

6. Mwekuru (having circumcized child). 
A Tharaka village usually consists of a dwelling-hut for each wife, a hut for cooking food, a hut for storing grain, one or more huts for the accommodation of goats, and occasionally a small hut for the owner to sleep in by himself. The whole is surrounded by a high thorn hedge with a small arched doorway about three feet high which is closed at night by drawing in a bundle of thorn branches. The dwelling-huts vary in size, but as a rule are not more than seven feet in diameter, and from six to eight feet in height at the centre. The walls are composed of sticks placed closely together to form a circle. These sticks are about four feet in height and are bound together by two continuous rings of wattle, one about two feet six inches above the ground, and the other at the top of the sticks. The doorway, which is about two feet three inches wide, extends up to the level of the lower band of wattle and is closed at night by a hurdle (irigi). Above the doorway the wall is continued up to the roof, but the sticks are placed horizontally. Standing about one foot out from the wall is a circle of posts about a dozen in number to which the ends of the rafters are fixed, presumably to give stability to the roof. The roof is thatched with grass, which is extended downwards to make an eave all round and finished up neatly on the top (Fig. 1). Inside a few forked stakes are driven into the ground and other sticks fastened across them to form a bedstead. This is generally about three feet from the ground and covered by a sleeping mat (ithithu), made of grass and bound with M'buyu thread (from bark of Baobab tree). The roof is used very largely for the storing of household utensils, especially when the hut is also occupied by goats, which is not infrequently the case, especially when the hut is that of the second or third wife.

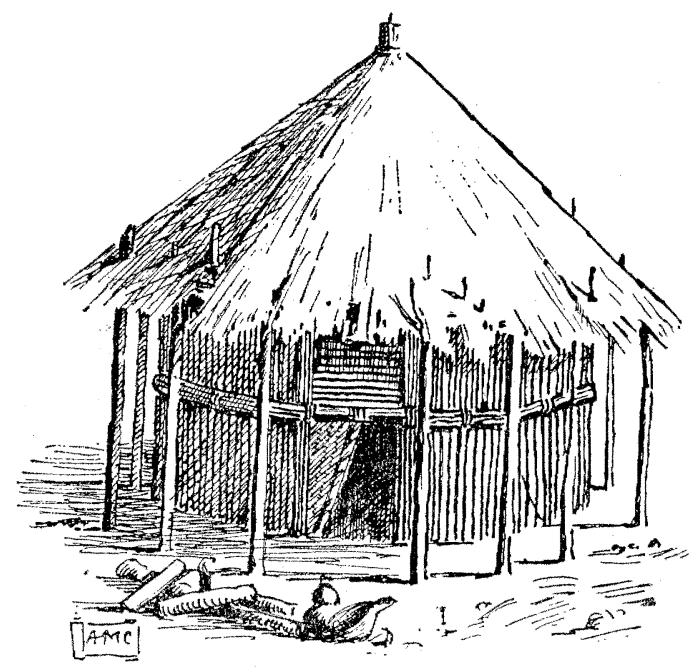

FIG. 1.

The huts used for kitchens and stores are built in a similar manner, but larger, and frequently better turned out. The doorway is not closed by a hurdle but with logs of wood (Fig. 2). In the kitchen one usually sees a fire burning 
near the doorway and a litter of utensils on all sides-calabashes, nzelis, earthenware cooking pots, millstones, chiondos.

If there be no other hut for storing the threshed grain, a kinga or two will probably be put in the same hut resting on a little platform (vide Plate X). As a general rule, however, there is a special hut built to place the kingas in, and walls are sometimes ornitted in the construction of these huts, their place being taken by a dozen or more strong uprights. Huts precisely similar to those for sleeping are built for the accommodation of goats, the doorway of these is closed in the same manner as that of the stores. Sometimes, but not often, one sees very small huts (vide Plate $\mathrm{X}$ ) with a small bedstead inside. These huts have no proper walls, and are used by the owner of the village to sleep in. They can hardly be called huts, they are nothing more than grass shanties.

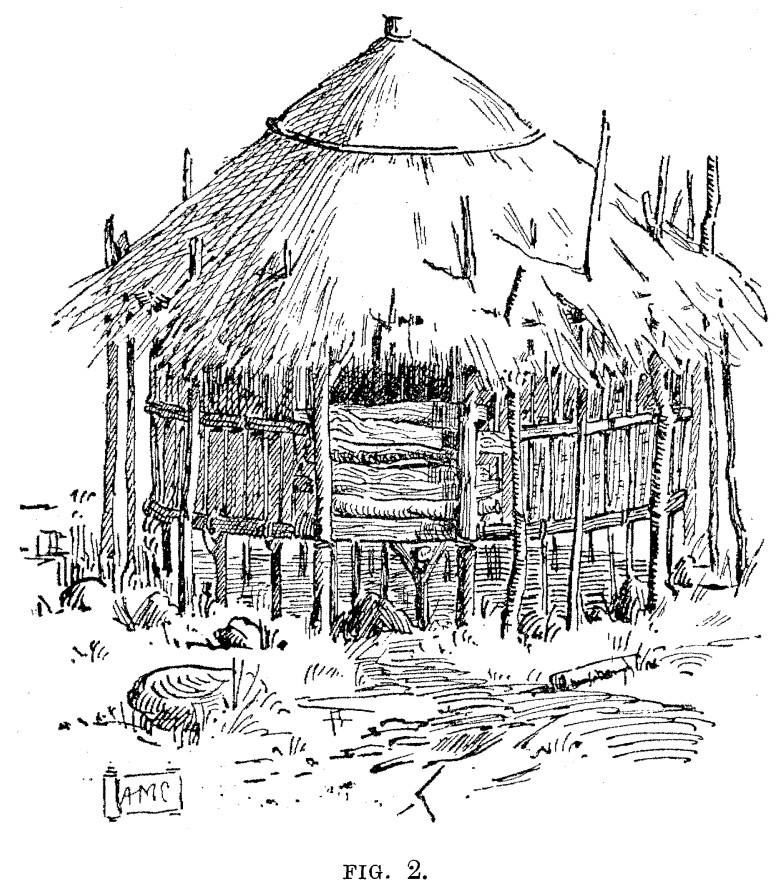

I am informed that these huts were usual a few years ago, but owing to the possibility of being taxed for them, the owners of villages are ceasing to build them. Small and very neat little huts are built on high stakes for the accommodation of chickens, but an old honey barrel seems to be more commonly employed. If there is an unmarried girl in the village whose mother is dead, she will live in a separate hut which is attached to the village, but generally surrounded by a separate fence. No unthreshed grain can be brought into the village, and for this reason large stores (Fig. 2) are built outside the fence. These huts are similar to the others, but the floor, which is constructed of wattle, is raised some eighteen inches off the ground; the top of the roof is about ten feet high, and the diameter of the hut about ten feet. When the store has been filled up with Mweli 
cobs the door is closed by piling up logs held in place between the door posts and two outer posts.

The unmarried men, and those whose children are not yet circumcized, cannot sleep in the villages unless they are sick. In each settlement, therefore, the young men or ngoromo build for themselves one hut generally hidden in a thicket close to the settlement. These huts are perfect works of art. They are about 20 to 25 feet in diameter, and from 10 to 14 feet high, and built of very stout, wellfashioned poles. The doorway is about $3 \frac{1}{2}$ to 4 feet in height, and extends up to the level of the eave. The walls are composed of stout posts placed into the ground close together. One enters by a sort of wattle passage, which is, in reality, the closed-up ends of a continuous sort of wattle bedstead running completely round the whole hut; standing in the middle it gives one the impression of a circular saloon with berths all round. These huts are never occupied during the day, and I have never found any signs of habitation, except a fire.

The care with which these huts are built and the excellence of the workmanship struck me very favourably.

The uncircumcized boys also build similar huts. These, however, are smaller and generally much closer to the settlement. The occupants sleep on the ground, there being no bedstead or similar contrivance.

\section{Method of Construction of Huts.}

The dwelling and goat huts are built without a centre pole or supports. A circle is drawn on the ground where it is desired to erect the hut, and the sticks forming the wall are driven in and bound with wattle, as before described. The rafters are then bound on to the upper wattle band, and fastened at the apex until it is considered that sufficient rafters have been put in. Another wattle band then secures the rafters about midway between the eaves and the apex.

In the construction of the larger huts five upright posts are placed at regular intervals under this band of wattles to bear the weight of the roof. In some of the ngoromo huts I have seen a single centre pole used. The circle for the walls is always very well described, and I am told this is done entirely by eye, no mechanical contrivance of any sort being used.

\section{Dress and Personal Adornment.}

Clothes.-The only clothing originally worn by the men was a fringe of mbuyu threads (ngigi) covering the genitals and the anus. The older men would sometimes wear goatskins fastened over the shoulder; all the hair from the skins was removed, and grease and red mud rubbed in. Now, however, trade blankets are being worn, but are by no means universal, as with the Akamba. The Ngoromo all wear the ngigi, and some now wear calico saturated in grease and mud in the place of the goatskins. Boys up to the age of about six or seven 
wear no clothing, but on reaching this age wear the ngigi, to which is frequently added a piece of goatskin in order to more effectively conceal the fact that they are not yet circumcized. Women always wear a short kind of leather kilt (nguo), and on marriage a leather apron (kathari) is added. This is fastened over the shoulders by a couple of strings, and extends from the breasts to the genitals, towards which it tapers off to a point. Uncircumcized girls wear beads round the loins, to which is attached a fringe of mbuyu threads, so as to cover the genitals. The threads generally have little bean-like things affixed to the end. I took these to be seeds, but was informed that they were carved out of wood. They frequently wear a tail of goatskin covering the posterior.

Ornaments.-The accompanying sketches show most of the ornaments in use amongst the Atharaka. As with the Akamba the older men do not wear many ornaments. The lobe of the ear is pierced and extended as with the Akikuyu. Round the extended lobe the old men frequently wear an hour-glass-shaped cylinder made of spirally wound brass wire. This is called a ngotonggi (Fig. 3). Fastened on to the rim of the ear are often seen one, two, or three little discs (ndugira) made of brass wire. Very little else is ever worn by the elder men except perhaps an armlet of brass or iron wire, or a ring of ivory round the upper arm. The young men show a considerable amount of ingenuity in the decoration of their bodies. At an early age the lobe of the ear is pierced, and great care is taken in the gradual operation of its extension. A circular peg of wood is put in, and this varies in size and shape according to the owner's taste. These pegs (mituitu) frequently resemble tops, having a sort of handle at the top by which they might be set spinning between the forefinger and thumb. Another ear ornament, but not so common as the mituitu, is the marengo; this is a half-moon-shaped piece of wood, which extends round the back of the neck from the lobe of one ear to that of the other. I am told that this is only worn by young men who have few personal charms to offer the girls. Thin needle-like spikes of wood (ndorira) about 2 inches or 3 inches long are frequently stuck through the rim of the ear. They give no explanation for this, and I think it is done to keep a hole clear for the insertion of the ndugira later on. The neck is usually adorned with a number of iron wire necklets, some being of smooth, round, trade wire, others much heavier in construction ornamented with little notches. These latter are, I think, made by the local smiths. Armlets and bracelets of iron and brass wire are very generally worn, but the brass ones seem a recent introduction. Between the calf and the

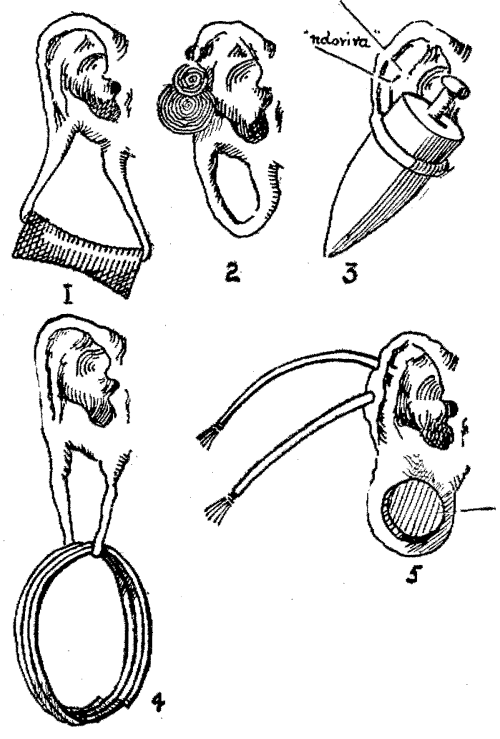

FIG. 3 .

1. Ngotonggi. 2. Ndugira.

3. Mituitu. 4. Matulutia.

5. Ndiro and Ndingi. 
knee a leather strap (ikuli) is frequently worn. It has two tails of leather hanging vertically from it, each about 5 inches or 6 inches long, running down the shin bone in front and down the centre of the calf behind; it is all cut out of one continuous piece of hide. I was repeatedly informed that this was an ornament, and worn for no other object. I cannot, however, help thinking that its origin, at least, must have been as a protection against thorns when walking in the bush. Anklets of black monkey skin are worn by the young men of position, but are not common. Anklets of brass, iron, or chainwork are worn by the majority. Before entering the dance the young men smear the legs with red mud and frequently

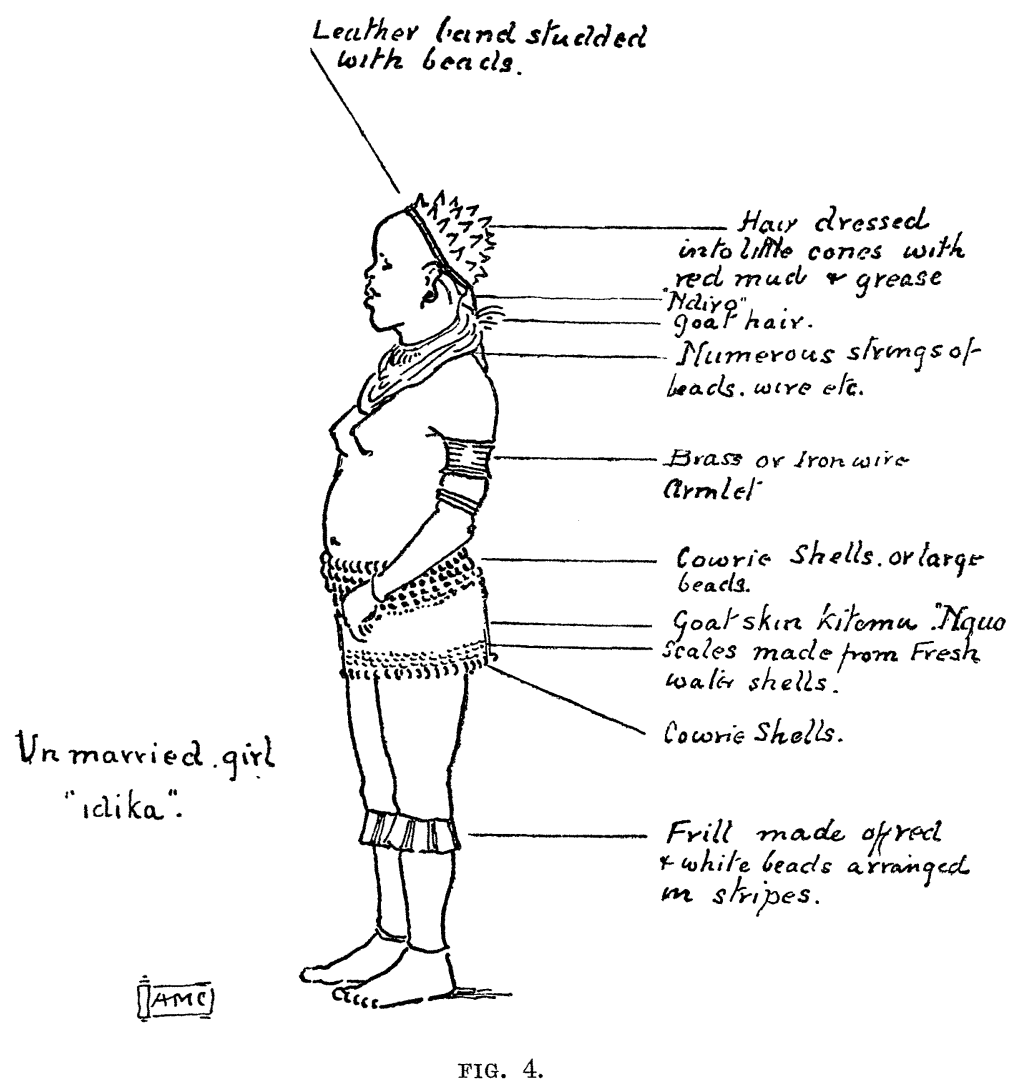

a great part of the body. Patterns are then picked out whilst the mud is still wet after the Masai fashion.

The women are literally weighed down with the weight of their beads and metal ornaments. The lobe of the ear is pierced, as with males, and extended. The ngotong'gi is not worn by women who wear the matulutia in its place (Fig. 3). This consists of about three or four coils of brass or iron wire about 3 inches in diameter. These are worn by all married women; in fact, I have never seen one without them. The neck is surrounded by a great mass of beads and wire. The beads are white and red trade beads. These were, I gather, worn by the Akamba some years 
ago, and were disposed of by them to the Atharaka, when beads of other colours were introduced. The kathari also is studded and edged with similar beads and cowrie shells. Numerous strings of beads are worn round the waist: the nguo is heavily adorned with beads, cowrie shells, and rows of scales made of the shell of the fresh-water snail, which is very common in the bush. No munyo (chain tassel) is worn behind as with the Akamba. Just below the knee a band of beads is worn ; these are so arranged as to form a sort of frill, the beads being so strung as to form vertical stripes of white and red. The ankles are sometimes similarly adorned. Armlets and bracelets, similar to those of the young men, are also worn by the women.

The unmarried girls do not wear the matulutia, but insert a small round piece of wood in the lobe of the ear (ndingi). They also wear goat's hair brushes stuck through the rim of the ear. These are called ndiro, and seem to serve no further object than decoration. The weight of these causes the rim of the ear to droop over, which I am informed is much to be desired. I was also informed that the ndiro flap about when the girls are dancing, which greatly fascinates the young men.

The Hair.-With the old men the hair of the head is usually shaven, but some allow it to grow to its natural length. Among the young men the hair of the head is most carefully cultivated, and when it is tardy in growth it is augmented with m'buyı thread. Thin coils of hair, well plastered with red mud and grease, is the appointed style for the young bloods. I watched the operation of augmenting the hair on one occasion. A friend took two strands of hair well plastered with red mud and grease, and twisting each carefully spliced in a piece of $m^{\prime} b u y u$ thread about five inches long, the whole was then rolled up tightly and pressed down to the side of the head. When this operation has been but recently performed it gives a curious effect, specially as the threads have a tendency to stand up at all angles, and it is not till they have been continually coated with grease and mud that they become indistinguishable from the hair. Sometimes one sees the hairs tied together in front and behind in a stubby pigtail after the Kikuyu fashion, but this is not common. The old women either shave the head completely or leave a tuft on the crown. The girls always leave a similar tuft, but tie it round with a thin leather strap in order to make it stand up (Fig. 4). The hair is thickly daubed with red mud and grease, either dressed so as to give a thatched appearance or dressed into a number of little cones, in which case the hair is quite invisible, owing to the thick coating of mud.

Beards are sometimes worn by the older men, but they are not the general rule.

\section{Arms.}

The Ngoromo, or warriors of the present day, carry spears of the Kikuyu fashion, but others have the leaf-shaped blade. These, I am told, are made by their own blacksmiths. Bows and arrows are also carried, but these strike me as being considerably smaller than those of the Akamba, but I have taken no measurements. 
The arrows are carried in a cylindrical quiver made of hollowed-out wood, and decorated with ostrich feathers. The arrows are similar to those carried by the Akamba, and the same system of marking the head is employed. A round-shaped flat head is used for drawing the blood from cattle, and barbed wooden heads are used for shooting birds.

Shields (longo) are not often seen now, except in the hands of the retainers of the chiefs. I am informed that they are carried by everyone in war. These shields are made of ox-hide stretched on a wooden frame, the rim being bound with thin strips of leather. The central main rib is very massive, and a slit is cut in the middle at the point of balance to insert the hand. Very curious patterns are picked out in black, red, and white; I can get no information with regard to the meaning of these, or whether they are representations of anything. I am told that all the Ngoromo living in one hut have the same device on the shield, but I am unable to verify this by observation. The artistic work on the shields is done by the wives or belles of the warriors. Red ochre, kaolin, and ashes are the pigments used for red, white, and black respectively. I have asked several Atharaka if they could tell me what clan the owner of a certain shield belonged to, and they have invariably told me they could not. I have recorded the devices on two shields which have come into my possession. A small wooden shield (ngao) is used in the dances, and for the boys to practise with. These are about two feet six inches long and about six or seven inches broad; a rib runs down the centre of the outer surface, and a kind of boss is made in the middle. A slot is cut at the back, which serves as a handle. The contestants each crouch on one knee, holding the shield in the left hand and a stick in the right. They then attempt to strike each other with the stick very much after the style of singlestick, and ward off the blows with the shield.

The Tharaka sword (luiyo), which is worn on the right side attached to the belt, is similar in pattern to that of the Masai, and is from twenty-eight to thirtytwo inches in length and carried in a red leather sheath. The blade is doubleedged and broadens towards the end, and then finishes off in a sharp point. The handle is made of horn or wood covered with goatskin. A rungu (njorma) with a stone head enclosed in a leather covering is generally carried, also on the right side and tucked into the belt. The latter is made of ox-hide about three inches broad and frequently horizontally ribbed and ornamented with beads. An axe (ithoka), similar to that used by the Akamba, is also carried on the belt. These are extraordinarily well-balanced and handy (see Plate $\mathrm{X}$ ). The shaft is about twenty-two inches in length. All these iron weapons are made by the native smiths.

I visited a smithy (kianda) situated on the west side of Mutialu Hill. It consisted of a round grass shanty, similar to the huts built for men to sleep in by themselves. A slight hollow dug in the ground and well lined with ashes constituted the forge. Two pillar-like stones (A) were set upright in the ground at one side about four inches apart. Between these and pointing downwards was 
a fireclay pipe (B) about eight inches in length. Wedged up in juxtaposition by means of stones was a wooden branched pipe of similar calibre (D). Tied on to the end of each branch by means of string was a long goatskin bag (miwa) (C) about two feet or more in length. In the bottom of each bag was a slit (c) (see diagram) like a mouth, the lips being composed of two pieces of wood ( $a$ ) held in the hand of the operator. Attached to the outer side of these two bits of wood was a leather thong $(b)$, long enough on the one side for the insertion of all the fingers and on the other side for the thumb only. Thus the operator by opening the hand opened the lips, letting the air into the bag. Then, by closing the hand quickly and pressing the two pieces of wood forwards and downwards, he drove the air through the pipes into the forge; he worked his hands alternately, with the result that an excellent draught was produced and the cinders glowed brightly.

To extract the iron from the sand a layer of grass is placed on the cinders, and on

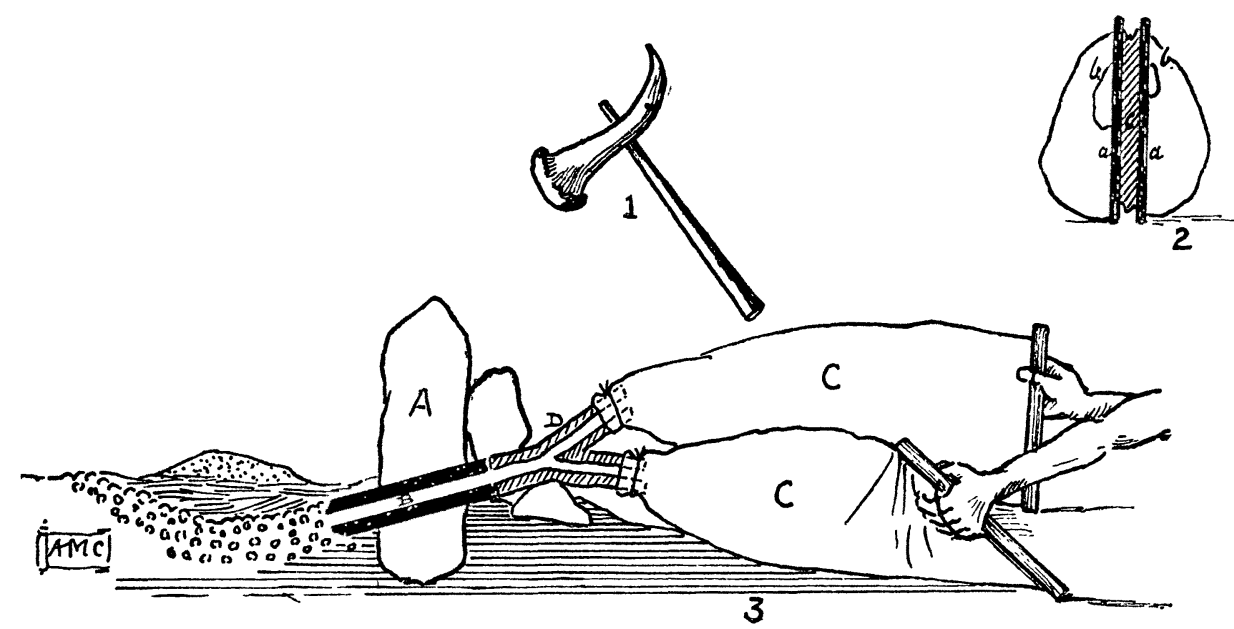

FIG. 5 .

1. Hammer (kiriba). 2. End view of bellows. 3. General diagram of forge.

the top of that is placed the black magnetite sand; the bellows are then applied and the heat soon causes the metal to amalgamate. A long pair of pincers (mgwadi) of the same pattern employed in a village at home are used to hold the glowing metal, which is hit into shape with the hammer (kiriba), a hard piece of stone being used as an'anvil. The hammer that I saw was very curiously shaped (see diagram) and fitted with a wooden handle. No other tools appear to be used.

The fireclay pipes are made from what I gather to be a mixture of mud and sand eroded from the deposits of murram, which are common all over the district. This mixture is modelled round a stick and put in the sun to dry. It is then baked hard in a fire.

I made some inquiries from the blacksmith as to where he got his knowledge from, and whether the Atharaka had always known the art or had acquired it from the Galla; but the only information that I could get was that his 
father had known before him, and that it was from him that he had learnt the craft. The smiths are regarded as distinguished men amongst the Atharaka, and their portion of the meat is always the shoulder. They are permitted to marry as they please, and there are no restrictions imposed on them in this respect, as I gather is not infrequently the case amongst other African tribes. A smith may belong to any of the Tharaka clans.

\section{FooD.}

The staple food of the Atharaka is muweli, but a good quantity of mbazi is also grown ; matama, kundi, ngenna (small beans in a long thin pod), and mobia (black beans) are also grown in lesser quantities. No maize is grown. The main shambas where the muweli and matama are grown are generally some distance from the village. Small huts are built for the storing of the grain, and the natives frequently sleep and reside there when there is a lot of work to be done in the shambas. There are extensive shambas on the east side of the main range of hills, and also along the Tana under Kisibi Hill.

The methods of cultivation are very primitive, but the shambas have a more tidy appearance than those of the Akamba. The soil appears to be very fertile. It is turned up with a mau stick, similar to that in use by the Akamba, and the sowing is done by making a hole with a long stick about 5 feet or more in length, and inserting three or four seeds.

The whole preparation of food, from the turning up of the soil to the boiling of the gruel, is entirely woman's work, but the men do much more work in the shambas than is the custom among the Akamba. A woman uses a mau stick without bending the knees, whilst a man always squats down with the shins doubled under the thighs.

The muweli cobs when ripe are picked off and placed in the food stores in the shambas, whilst the stalks are beaten down, and in this position are said to prevent weeds from growing up and choking the mbazi and matama, no doubt also giving shade to the roots and assisting the soil to retain moisture. When the harvesting is over, the cobs are threshed, either on a flat slab of gneiss, or on a piece of ground specially prepared with cow-dung. The grain is then stored in kingas in the villages. Sufficient grain is ground every day to supply the daily requirements of the village, as muweli flon very soon deteriorates, and will then cause severe attacks of diarrhœa. Grinding is also the work of women. This is done between two stones; the lower one (iiga) is very large, and tilted forward so that the flour works its way downwards and falls into the nzeli placed underneath. The rubbing stone (intheo) is held in both hands, and the whole weight of the body thrown on to the arms. These stones are of gneiss or granite, and when they wear too smooth they are roughened by means of a piece of quartz. After being ground the flour is mixed with water and ground again and again till a fine pap results. This is called usuu, and is allowed to stand till it ferments slightly and is then drunk. Beer (uki) is sometimes made from muweli, the grain being first soaked in 
water for three days and ground. It is then put into large earthenware jars (ikura) and fresh water added. This is then put to simmer over a fire for three days and allowed to stand for two or three days till a sufficient degree of fermentation is considered to have been attained. This, I am told, is a very powerful intoxicant. Mbazi is boiled whole frequently with its own leaves which are said to give it a particularly pleasant taste. Milk is drunk in large quantities and is used in the preparation of porridge.

Wild birds and fowls are not eaten except by uncircurncized children; eggs are not eaten by anyone. The reason that they give is that the circumcized people wish to make a distinction in the matter of diet between themselves and the uncircumcized. I suspect the existence of some other reason. Fish is not eaten by anyone; however, I am told that there is no prohibition, but that a man would be sick if he did so. Wild animals, cattle, sheep, and goats are all eaten by the Atharaka, but each person according to his sex, rank, relationship, and position in the village has his particular portion. The elder of the village eats the head, the heart, the front leg, and the spleen (wengo as in Kiswahili). The latter must not be boiled, but roasted, and eaten in company with other elders of the same standing as himself. The eldest wife in the village eats the hindquarters (muliro). The brother of the elder gets the other foreleg (kwoko), whilst his wife gets a hind leg (kuuru). The Ngoromo and male children get the chest (lutu), whilst the female children get the chops. A goat is cooked whole, and to each person is served out his portion ; the recipient can eat with the others if he wishes, or go away and eat separately. With regard to the eating of other food-stuffs, I am informed that they can all eat together, but that each person has his own nzeli. Authorities for the above particulars are Mundu wa Mirigi and Mundu wa Kaibero (son of Mzee Mbaibui).

Honey is much cultivated by the Atharaka, barrels (mwatu) being placed in the Mbuyu (Baobab) trees in the bush (see plate). The barrels are similar to those used by the Akamba, the ownership being established by brands which generally take the form of an arrangement of dots and strokes. The barrels are not infrequently made of the wood of the Mekoma Palm, which grows very plentifully along the banks of the Tana and of the rivers that run into it. This wood is very easy to work, and I am told possesses such a degree of pliability that if the barrel falls it is not broken. The barrels are hollowed out by means of a long chisel, the handle being about four feet in length. The bees are driven out by smoking, the operator removing one end of the barrel and placing inside a lighted bundle of twigs, which give off a great amount of smoke; he drives clouds of smoke into the barrel by blowing violently with his mouth and the bees evacuate. Honey is eaten, but is more frequently used for making beer; at present many tons of wax must be wasted every year. 
DANCES.

There are several varieties of dances, but I will only attempt to describe those that I have seen.

(1) Kisboso.-In this dance the men all carry a board (lukongoro) made of the Mukonguu tree. This is attached to the right wrist by a loop of string, so that the right hand is free to hold the stick (keusia) with which the board is beaten. The keusia consists of a bundle of kianduli twigs bound very tightly together; its impact with the board produces a deep sound like that of a muffled drum. The men partaking in this dance walk in single file, following the leader, who twists about describing circles round the person in whose honour the dance is being performed, at least such was done on all the occasions that I have witnessed this dance. The lukongoro are struck in slow time, and a low tremulous sort of chanting goes on all the time. No women take part in this dance.

(2) Nzungo.- The men form a circle and the girls stand in the middle. Then one man, apparently the leader of the dance, walks round beating a tomtom and singing in a shrill voice. When this song is finished the men rush inwards and with shouts and howls leap several times into the air and return to their places. The girls then each advance and choose their partners by touching them lightly on the hand. The singing is resumed by them all, and the chosen men advance towards their partners and clasp them lightly round the waist, whilst the girls place their hands on the men's shoulders, each facing each other. They both bend their knees in rhythm with the singing of the others, but they do not sing themselves. The men gently stroke the backs of the girls with the palms of their hands. The man with the tomtom then strikes up again and the dancers resume their places, and the performance is repeated.

(3) Mungeri.-This dance is very similar to the Nzungo, but the partners each place their hands on the other's shoulders, jigging up and down with their faces touching. This dance is done in double time and accompanied by rapid and riotous singing. It is sometimes performed by the men alone, in which case they stand their shields up in front of them and rest their hands on the apex, or if they have no shield clasp their spears with both hands at the point of balance. I have seen old men participate in this dance.

(4) Mboboi.-This dance is reserved for the circumcision ceremonies and other great occasions. This, I think, I have only seen in a modified form, as it is extremely sensual in character, and I think they are disinclined to dance it fully in front of a European. As far as I have seen, the men and women do not mix in this dance but each have their separate dances. The men stand in a circle to the accompaniment of singing. Then one or more spring out from the circle and run round in circles keeping one leg always to the front. Then with a grunt and a shout wheel round suddenly and finish the performance with a sudden hollowing of the back apparently with the object of jerking up the ngigi and exposing the private parts. He then returns to his place and another carries on the same performance. The performers display the greatest agility. 
The married women have a very similar dance, but instead of running round with one leg to the front they advance by short jumps, the knees being kept bent and close together and the hands placed on the hips. The performance is finished by a sudden holiowing of the back and contracting of the muscles of the abdomen with apparently the same object as that described above. I have seen unmarried girls also taking part in this dance. The words which they sing are very much what one would expect: they were interpreted to me thus: the married women sing " the Ngoromo come every day to the village in search of something. Now Matika we know what it is they come to look for, show us what it is!" From this, I presume, it is usual for married women and girls to dance this in conjunction.

I do not know whether there are different dances for different seasons of the year, but these are the dances that I have seen on both my visits to Tharaka.

\section{MEDicine.}

On entering Tharaka I found across the path, which at this point passed through a shamba, two posts set up on either side of the path with a crosspiece making a sort of doorway. On the crosspiece was hung the leg of a goat, this I was informed was placed there by a medicine man (muao) to prevent wild animals from destroying the shamba. Where the path left the shamba a similar contrivance had been erected. In a large number of the villages I visited there were similar constructions with the cross-piece placed through an earthenware pot of which the bottom had been knocked out. This, I was on every occasion informed, was to ward off illness among the cattle.

In another village I found two forked sticks planted in a sunken earthenware pot and placed in the fork of the sticks was a piece of hedgehog's skin, a lump of quartz, and a piece of cowdung. This, I was informed, had been placed there for a similar reason.

It appears that young men who have but recently been circumcised are very susceptible to evil influence. Hence the services of a medicine man are engaged to place medicine near the village to prevent the approach of anyone possessing an evil spirit. On two occasions I found this medicine to consist of a piece of calabash tied to a stick which was planted in the ground by the side of the path. The piece of calabash was pierced by a number of long thorns and presented very much the appearance of a pincushion.

\section{Soctal Laws and CUSTOMS.}

(1) Birth.-On the birth of a child the father must call together his relations and slaughter a goat. This ceremony takes place outside the village, for no one can enter the village for five days after the birth. Should the father himself be away at the time of the birth he cannot himself enter the village till the goat has been slaughtered. During this period of five days no property can leave the village. 
(2) Hirst shaving of the head.-A child's head must be first shaved when it has reached the age of six months. The operation is performed about 2 p.m., and in the evening a goat is killed and eaten by the relations, who then cut two thongs from the skin and fasten these round the shoulders of the child. Then they all wash their hands in the gruel (usuu) and bespatter the mother with it. On the same night the mother and the father must cohabit, and on the next day normal conditions prevail again in the village.

(3) Circumcision.-Both boys and girls are circumcized. The foreskin apparently is not cut off as with other tribes, but a large part is left to hang down from under the penis. I do not as yet know anything of the circurncision rites.

(4) Marriage.-A man must always choose a wife from another clan. The usual dowry paid is thirty goats ; it may, however, be more or less, but it appears that thirty is the normal number. Besides these goats a kilembi $i^{1}$ of honey, an axe, and an iron necklace are also paid. From five to ten of these goats are generally given as a marriage portion, by the father, to his daughter.

For a period of four days from the day on which a wife first enters her husband's village no one is allowed to enter that village or that from which she came. In several villages I noticed young women wearing long aprons similar to those worn by all married women but extending below the knee. I inquired on two occasions the meaning of this, and was informed each time that these were recently acquired wives, and that it was customary to wear these long aprons till they were worn out and only then were they allowed to don the married woman's kathari.

When a Ntheka or Ngoromo takes a wife he must pay a goat to a Ntheka Nguru who in turn pays a goat to a Kisungi. Thus they all move up a grade and no overcrowding results.

The Atharaka are polygamists, but very few own more than two or three wives at most.

(5) Death.-I do not as yet know what ideas the Atharaka entertain of death. The dead body is thrown into the bush; this is the work of the wife or son of the deceased. Very old and much respected men seem, however, to be honoured with some sort of burial, but women are never buried, whereas amongst the Akamba the first wife is always buried. A goat is killed and eaten by all the Akuru of the settlement, the burier's portion being the skin and one leg. The Akuru direct the burier on which side the body shall be laid. The body can then be thrown into the bush. The brother of the deceased must, however, have connection with the wife of deceased on the fifth night after the death. The performer is called Thela Luku. This custom also prevails amongst the Akamba, the man being known as Kuana. The normal life of the village can then be resumed. The hut of the deceased, if he was a married man, must be vacated and allowed to rot away. When a child dies the body is stripped of all clothing and ornaments, but these are placed in a little heap by the side of the body in the bush. The spear and shield of a Ngoromo are also placed alongside the body. No property is buried

1 A wooden drum in which honey is kept after extraction from the hive or barrel. 
with married men; it is inherited by their sons. I was informed that theft of these things was quite impossible, and that any man who did so would at once be suspected of having compassed the death of the owner and would be cast out by his people.

Civil and criminal law.-The penalties for breach of the law seem to be less constant than among the Akamba, and the greatest difficulty has been experienced by others as well as myself in codifying even the commoner offences and their penalties. The unit of payment is one goat. Cattle are never given in payment of a penalty or dowry. As with the Akamba so with the Atharaka, no crime is so serious that it cannot be atoned for by payment.

(1) Murder.-From forty to sixty goats, one honey barrel, one iron for marking same (choro), one axe and one sheep, which must be slaughtered, constitutes the usual payment. The offender must pay as many goats himself up to twenty as he is able from the stock in his own village, the balance being paid by his clan. The other articles he must pay himself. The honey barrel must be made of the wood of the Movinga tree, which I am informed only grows on the north side of the Tana.

If a man kills another of the same clan he has to pay only thirty goats, a choro, and a sheep. This, however, was disputed by the elders at Kiema's, who said the blood-money was the same, but ten of the goats had to be slaughtered on the spot and eaten by the whole clan. It is important in making all payments that all the goats are handed over the same day.

The compensation for a woman is the same, but the goats are reduced to thirty. This also was disputed by the elders at Kiema's, who said that fifty-four goats, one kithembi of honey, and an iron necklace was the correct payment.

No mbanga or manslaughter seems to be recognized. Should a man survive a rain after having been struck, i.e., six months, he is considered to have got over his injuries, and no payment can be claimed when he dies. Others, however, assert that should he never recover his full faculties, and his subsequent death be deemed by the Akuru to be due to the original injury, the offender can be called upon to pay full blood-money. The body is never cut open after death as is common with the Akamba. On causing a man injury of any kind, a goat should be paid immediately by the offender. If this is done and the man dies of the blow, his spirit (?) will not bring evil or misfortune on the village of the man who caused the injury.

(2) Loss of arm or leg.-One goat should be paid on the spot, but no further payment if the arm or leg withers or is lost. Others said that they have known seven to sixteen goats paid for the loss of the leg. The elders at Kiema's denied this and stated that seven goats might be paid if the arm or leg were cut right off.

(3) Loss of eye.-Seven goats appears to be the usual payment. One old "mukuru" was very persistent in asserting that it was seventeen in old times, but he was not supported on this point by the others. However, the elders at Kiema's said that fourteen was the correct number. If the left eye is the disabled one the goats paid must be handed over to the people of the sufferer's mother; if the right, the goats must be kept by his father's people. 
(4) Loss of ear.-No payment for tearing the lobe of the ear (this is curious, as the Atharaka extend the lobe, and amongst other African tribes who do so I understand that a heavy penalty is inflicted). I was afterwards told that should the ear be cut right off one goat might be paid.

(5) Loss of testicles.- Same as for murder; the goats are paid at once and divided amongst the clan, but the other articles are not paid till the sufferer dies. Others say that the offender must give him a wife for the use of his brother.

Free love is permitted amongst the unmarried men and girls, but on her marriage it is the duty of the girl to tell her husband the names of all those Ngoromo who have had connection with her, and they must each bring a goat to the husband's village. Should a man cause a girl to conceive he must pay fourteen goats to her father at once. It is then open to him to offer to take the girl in marriage, but these goats do not reckon as part of the dowry. If there is no marriage the child becomes the property of the girl's father. If the girl subsequently marries she does not take this child to her husband's village, unless he pays her father five extra goats. These goats it is customary for the father to give the girl.

(6) Adultery.-On this subject there was a great diversity of opinion ; at Kimundi's and Kivuvi's I was informed that seven goats were paid and the offender had to take a public oath that he would in future leave the woman alone. Others said that the payment was one large male goat and two female goats. The elders at Kiema's confidently asserted that two goats (one male and one female) was the customary penalty, and that one must be slaughtered and one kept alive; should the woman at any time be taken ill the ear of this must be cut and the blood sprinkled on her breasts.

No further payment is imposed if the woman gives birth, but should she die in child-birth full blood-money could be claimed.

(7) Theft.-The possibility of theft seems to be so little considered that no definite provisions are made against the committal of this and similar offences. For honey-stealing, however, a penalty of seven goats is imposed for every offence ; death is never inflicted no matter how many times a man offends. If women or uncircumcized youths steal anything they must return the article, together with two goats, one of which must be slaughtered and eaten by the Akuru.

\section{The Chiama.}

To make a Mukuru ya Chiama a Kisungu must undergo a probationary period with the Akuru ya Chiama, and then if he is considered to be a man of wisdom he can become one of them by payment of two goats. He has then the right to sit on the Chiama. There are Ngoromo ya Chiama, who wait on the Akuru ya Chiama; whether these are undergoing probationary periods or whether their functions are purely those of servants of the court I do not yet know, I am told that a part of their work is to cut up and distribute the meat. Inside the Akuru ya Chiama are the Akuru ya Nthuli, whose special function is to arrive at decisions, and for this purpose they go apart just as the Nzama of the Akamba. 
It appears that the Chiama are a very elastic body, not meeting at any particular place nor consisting of any specified members. For instance, a man A of one district has a dispute with a man B of another district, they cannot arrive at a satisfactory agreement between themselves, so A goes to B and says, "We will call a Chiama." Then A goes and collects the Akuru of his neighbourhood and $B$ does the same. When they are ready they appoint a place of meeting convenient to both, and the Akuru ya Chiama collect there and hear the case and give judgment. The chief of the district is not necessarily called into the case at all. The same applies to clans as to districts, no outsiders from other districts or clans are required to sit, or need be informed of the proceedings.

There was no fixed Chiama, before which all cases must be brought. It was merely a settlement by the elders who were concerned or had knowledge of the case. According to circumstances the elders of one district might sit in Chiama with the elders of one district one day and with those of another the next. It was just a method of settling disputes which grew up amongst a people essentially democratic.

Chiefs, as we understand the term, were non-existent, but there was in every community a man whose influence was predominant, generally two, one, so to speak, a civil consul, and the other a military dictator. The latter have been most frequently accepted by the Government, as their names were the first presented. It is, after all, natural that these men should have been mentioned to the European, whom the Atharaka no doubt regarded as their common enemy. But a chief did not hold a Chiama at his village, though it would no doubt frequently be held there if his advice or evidence were required. Centralized systematic Chiamas, such as the Government have instituted amongst the Akamba, would be most unacceptable to the Atharaka. Should a quarrel arise between two men of the same clan with regard to the distribution of property, the matter, I was informed by Tuto and Kivuvi, would be settled in the following manner. The Akuru wa Chiama of the clan would each subscribe a goat, and the goats so collected would be exchanged for a bull. This would be done without the knowledge of the two parties, who would then be called to the Ithembo. The bull would then be slaughtered and eaten by all present and the matter would be explained to the parties, who would be required to take a most solemn oath on the bull that they would cease to quarrel over this matter, and that, if they did so, they must now expect to die. Any remaining goats would be then distributed amongst the parties according to the decision of the Akuru.

When a Mukuru wishes to speak in the Chiama, he does so by singling out one man from the rest to whom he addresses his remarks, as if the others were not present, the duty of the man so addressed is to repeat the last few words of every sentence. The sentences are usually short and impressive on these occasions. It would be quite contrary to custom to address a man directly if you wanted to speak to him or to accuse him, a third person must always be addressed.

The Clans.-My enquiries concerning the clans of the Atharaka have up to 
date been very unsuccessful. I am at present quite at a loss to find any system. It would appear that a clan is generally named from its founder or original head : some have a totem (?) or forbidden thing, others have not. Each clan has its own cattle brand. Below I have made out a table which may perhaps serve as a basis for future investigations.

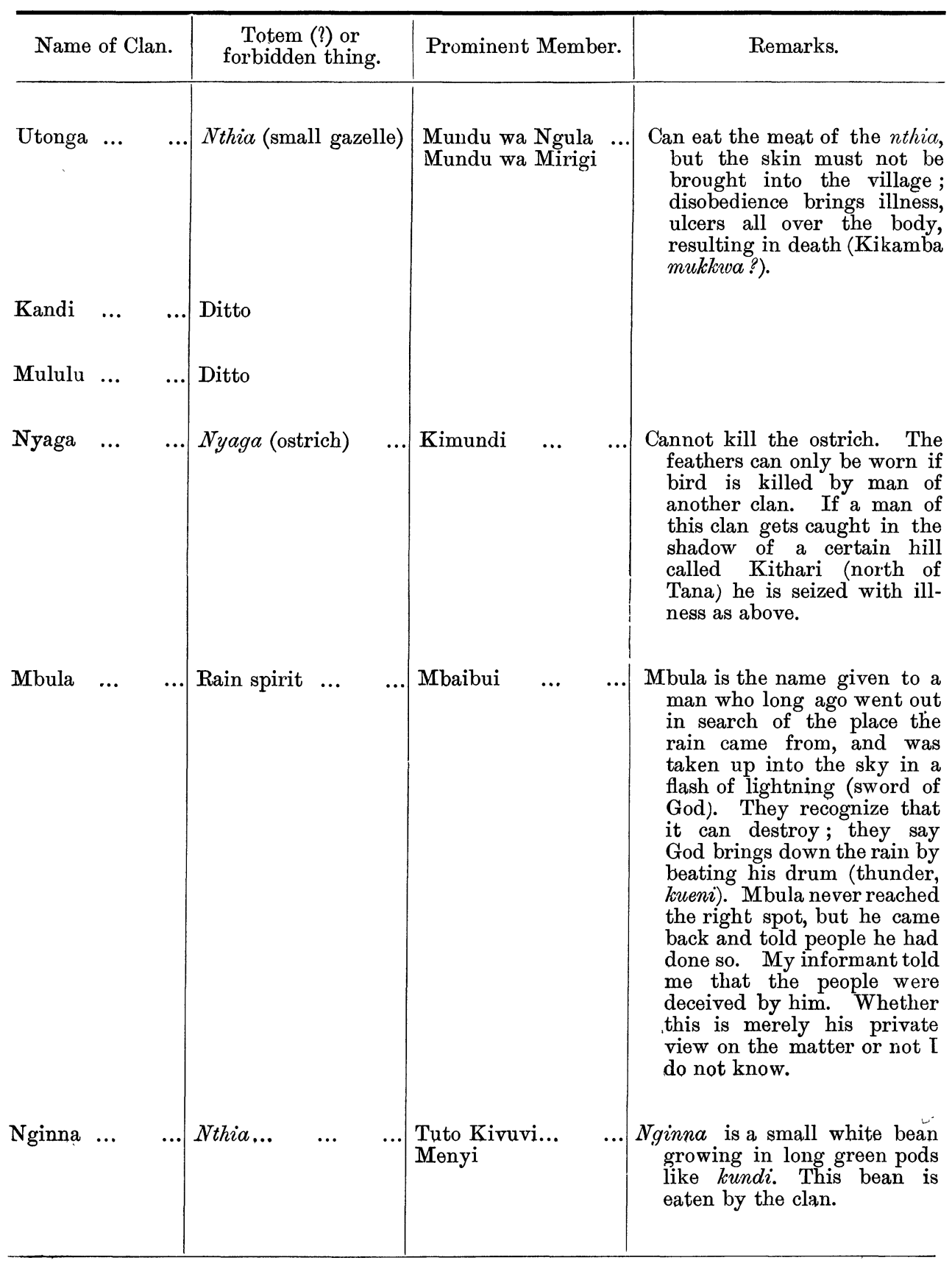




\begin{tabular}{|c|c|c|c|c|c|c|}
\hline \multicolumn{2}{|c|}{ Name of Clan. } & \multicolumn{3}{|c|}{$\begin{array}{l}\text { Totem (?) or } \\
\text { forbidden thing. }\end{array}$} & & \multirow{2}{*}{$\begin{array}{l}\text { Remarks. } \\
\text { Cannot be smiths ; because in } \\
\text { the past so many were } \\
\text { smiths, that one day they } \\
\text { were all surprised by their } \\
\text { enemies whilst at work in } \\
\text { the forges, and the clan was } \\
\text { nearly exterminated. After } \\
\text { that they vowed that they } \\
\text { would never return to the } \\
\text { work which had been so } \\
\text { disastrous. }\end{array}$} \\
\hline Kamurigi & ... & Nthia ... & $\cdots$ & & & \\
\hline Ndue & $\ldots$ & None ... & $\ldots$ & & $\cdots$ & $\begin{array}{l}\text { Ndue is name of original head } \\
\text { of clan. }\end{array}$ \\
\hline Kanzero ... & ... & Nthia... & $\ldots$ & .. & $\ldots$ & $\begin{array}{l}\text { Kanzero is name of original } \\
\text { head of clan. }\end{array}$ \\
\hline Kamararo & ... & Wild pig & ... &. & $\ldots$ & $\begin{array}{l}\text { Kamararo is name of original } \\
\text { head of clan. }\end{array}$ \\
\hline Mutwa ... & ... & None ... & ... &.. & $\ldots$ & $\begin{array}{l}\text { Mutwa is name of original } \\
\text { head of clan. }\end{array}$ \\
\hline Kamogwe & $\ldots$ & None ... & $\ldots$ &.. & $\ldots$ & $\begin{array}{l}\text { Kamogwe is name of original } \\
\text { head of clan. }\end{array}$ \\
\hline Kanthakami & $\ldots$ & None ... & $\ldots$ &.. & $\ldots$ & $\begin{array}{l}\text { Kanthakami (blood) is name } \\
\text { of original head of clan. }\end{array}$ \\
\hline Kathoga... & ... & None ... & $\ldots$ & .. & $\ldots$ & $\begin{array}{l}\text { Kathoga is name of original } \\
\text { head of clan. }\end{array}$ \\
\hline
\end{tabular}

General.

If a woman runs away from the village of her husband, he cannot cohabit with his other wives till she returns. If he does so he must slaughter a goat before she can enter his village again.

It is the first duty of every woman on rising to fetch water ; this is done in calabashes, several being carried at a time by means of two wattle frames carried on the back. The calabashes are placed between the two frames, there being large holes or sockets into which they fit. The frames are then strapped tightly together and the whole slung on the back, the weight being taken by the leather strap placed over the forehead. It is a serious breach of custom for a woman to leave her village without water in it.

The women are very industrious and neat with their hands: some make excellent baskets (see Plate $X$ ), and I am told that the Akamba freely exchange their beads for the Atharaka-made chiondos.

The Matika cannot remain in the presence of the Akuru; she must go away when they approach. I have seen this take place many times whilst I was in the villages taking the census. 
At the time of my visit there was little or no work to be done in the shambas, and I usually found the whole family perched on the top of a rock close to the village. They formed a most picturesque group, each member at work on something: the old women weaving chiondos or making string (they plait an excellent cord from the fibre of the mugaar tree), and the girls fashioning ornaments with leather and beads. The men at that time were very busy with the construction of their honey barrels.

Tobacco is universally grown, but only in small quantities; each man grows for his own requirements, but I am told that it is much sought after by the Akamba as its flavour is particularly good. Some of the old men smoke pipes (morangi), whilst others take snuff (see Plate $\mathrm{X}$ ).

The horns of the bush-buck are much prized as they make very convenient snuff-boxes. The horns of the water-buck are made into musical instruments, one of which is nearly always to be found hung up in a village. These horns do not appear to be used in the dances and I do not know to what purpose they are put.

Fire is produced by rubbing two sticks together. The fire-stick (girik $\alpha$ ), made of the wood of the muranguti tree, is notched at the edge, and the rubbing-stick (urindi) is inserted, together with a little fine sand. The rubbing-stick is made of the wood of the nurindi tree and is very hard (see Plate). This stick is twisted rapidly between the palms of the hands till smoke is given off and a little fine charcoal results. Then a little dry grass is put to this and gently blown till a flame is kindled.

The Atharaka are very expert in the manufacture of poisons, and apparently use this knowledge very frequently for the disposal of their enemies. It is therefore the custom for a man to partake of a morsel himself before offering food to another. The custom is universal, and no offence whatever would be taken should a man forget to do this, and in consequence his guest pointed out the omission. I have noticed that Akamba are very particular with regard to its observance when accepting food from the Atharaka. 

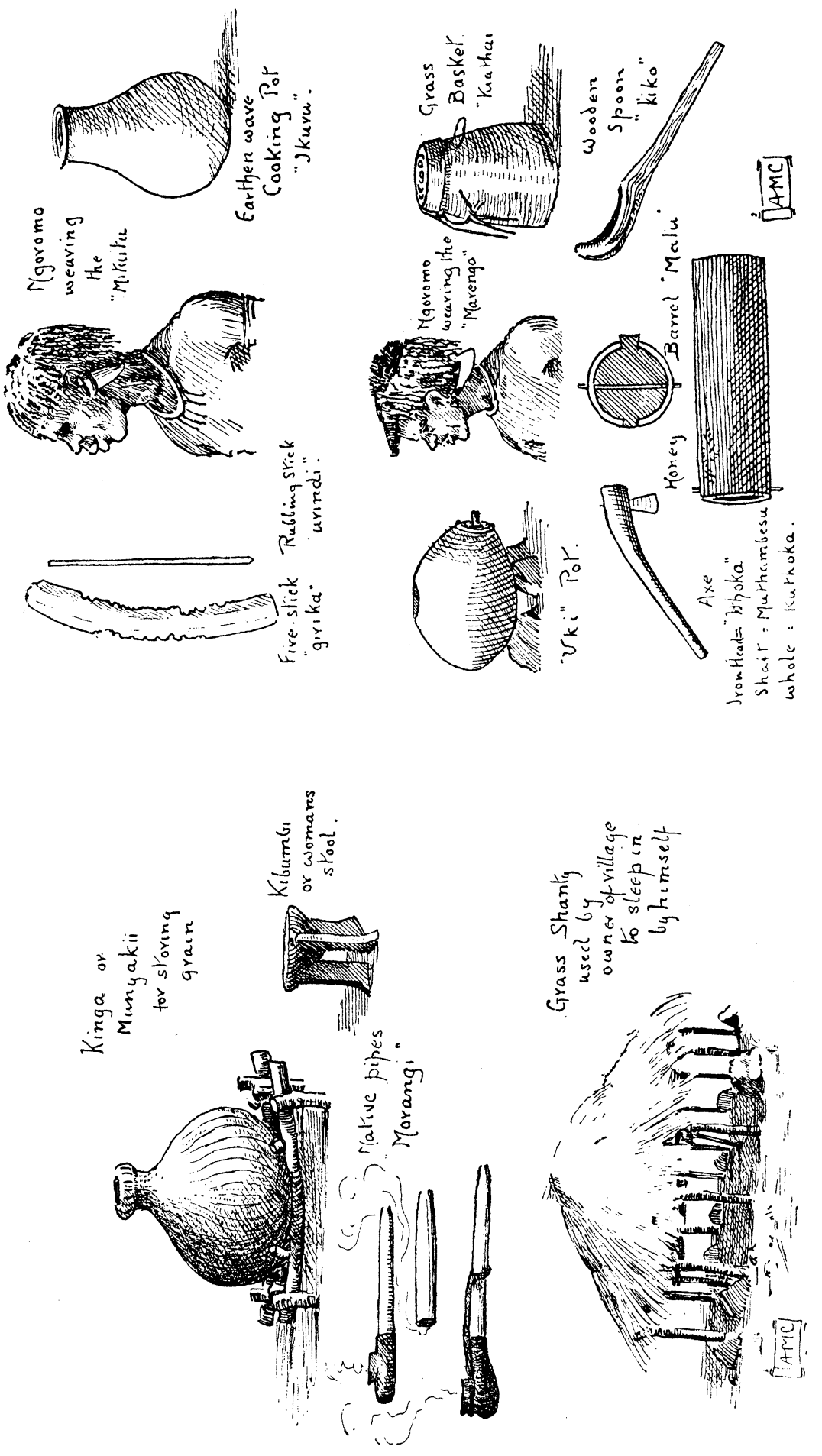